\title{
HPV type infection in different anogenital sites among HIV-positive
} Brazilian women

\author{
Maria Alice G Gonçalves*1, Giorgia Randi², Annie Arslan³, Luisa L Villa4, \\ Marcelo N Burattini ${ }^{5}$, Silvia Franceschi ${ }^{3}$, Eduardo Antonio Donadi ${ }^{1}$ and \\ Eduardo Massad ${ }^{5}$
}

\begin{abstract}
Address: ${ }^{1}$ Division of Clinical Immunology, University of São Paulo, São Paulo, Brazil, ${ }^{2}$ Istituto di Ricerche Farmacologiche "Mario Negri", Milan, Italy, ${ }^{3}$ International Agency for Research on Cancer, Lyon, France, ${ }^{4}$ Department of Virology, Ludwig Institute for Cancer Research, São Paulo, Brazil and ${ }^{5}$ School of Medicine, Department of Pathology, University of São Paulo, São Paulo, Brazil

Email: Maria Alice G Gonçalves* - epigin@uol.com.br; Giorgia Randi - randi@marionegri.it; Annie Arslan - arslan@iarc.fr; Luisa L Villa - villall@hotmail.com; Marcelo N Burattini - mnburrat@usp.br; Silvia Franceschi - franceschi@iarc.fr; Eduardo Antonio Donadi - epigin@uol.com.br; Eduardo Massad - emassad@usp.br

* Corresponding author
\end{abstract}

Published: 14 March 2008

Infectious Agents and Cancer 2008, 3:5 doi:10.1186/1750-9378-3-5
Received: 26 September 2006

Accepted: 14 March 2008

This article is available from: http://www.infectagentscancer.com/content/3/l/5

(c) 2008 Gonçalves et al; licensee BioMed Central Ltd.

This is an Open Access article distributed under the terms of the Creative Commons Attribution License (http://creativecommons.org/licenses/by/2.0), which permits unrestricted use, distribution, and reproduction in any medium, provided the original work is properly cited.

\begin{abstract}
Objectives: To evaluate the prevalence of human papillomavirus (HPV) types, and risk factors for HPV positivity across cervix, vagina and anus, we conducted a study among 138 women with human immunodeficiency virus (HIV).

Goal: Compare the prevalence of different HPV types and the risk factors for HPV positivity in three sites.

Results: The most frequently detected HPV types in all sites were, in decreasing order, HPVI6, $53,18,6 \mathrm{I}$ and $8 \mathrm{I}$. Agreement between the cervix and vagina was good (kappa $0.60-0.80$ ) for HPVI6 and 53 and excellent (Kappa > 0.80) for HPVI8 and 6I. HPV positivity was inversely associated with age for all combinations including the anal site.

Conclusion: In HIV positive women, HPVI8 is the most spread HPV type found in combinations of anal and genital sites. The relationship of anal to genital infection has implications for the development of anal malignancies. Thus, the efficacy of the current HPV vaccine may be considered not only for the cervix, but also for prevention of HPVI8 anal infection among immunossuppressed individuals.
\end{abstract}

\section{Background}

More than 1.7 million people were living with human immunodeficiency virus (HIV) infection in Latin America at the end of 2004, and Brazilian women made up more than one-third $(610,000)$ of this population [1]. Among women from 15-24 years of age, the prevalence of HIV infection in Brazil is estimated to be $0.5 \%$. With the advent of antiretroviral drugs in Brazil, median survival time for people diagnosed with AIDS has increased from 18 to 58 months [2].

Epidemiological and laboratory data have demonstrated that persistent infection with high-risk human papillomavirus (HPV) types (like 16, 18, 31, 33, 39, 45, 52, 53, 56, 
$58,59,66,68,73,82)$ is an essential step in the development of invasive cervical cancer and the majority of anal cancer [3]. Compared to HIV-negative women, HIV-positive women have an increased incidence and persistence of HPV infection and a concomitant increased risk of developing squamous intraepithelial lesions and cervical cancer [4-7].

In addition, compared to HIV-negative women, HIV-positive women show a higher occurrence of multiple-type HPV infection [8-10] and a relatively lower proportion of HPV16 [11]. Little information is available on the concomitant prevalence of HPV infection in different anogenital sites [12], notably in the anal area $[13,14]$.

In this study we have compared the prevalence of different HPV types and the risk factors for HPV positivity in three sites (i.e., cervical, vaginal and anal area).

\section{Methods \\ Patients}

Study methods have been reported elsewhere [8]. Briefly, a cross-sectional study was conducted among 138 HIVpositive women, aged $19-57$ (mean age $=31$ years), who attended the Center of Reference in AIDS of Santos, São Paulo, Brazil between June 1996 and April 1997. Patients who reported previous hysterectomy, virgins or those who were not able to provide an informed consent form were excluded from the study. All women underwent HIV serological testing with Western blot confirmation (Cambridge Biotech Corporation, Worcester, Massachusetts, USA). CD4 cell count was performed on the date of the visit or within three months thereafter. CD4 counts were $>500$ cells $/ \mathrm{mm}^{3}$ in $24.6 \%$ women, between $200-499$ cells $/ \mathrm{mm}^{3}$ in $37.0 \%$, and $<200$ cells $/ \mathrm{mm}^{3}$ in $38.4 \%$.

The same gynecologist applied a standard questionnaire for all patients to elicit information on sociodemographic characteristics, smoking habits, history of drug addiction, sexual behavior and use of condom. The Ethics Committee of the Medical School of the University of São Paulo, Brazil, approved the study protocol, and all participants signed informed consent forms.

\section{Sample collection}

The same gynecologist collected exfoliated cells from 1) ectocervix, 2) vagina and 3) anal area, in that order, with separate sterile brushes, and stored in separate flasks in phosphate-buffered saline solution (PBS). To obtain samples for anal collection, individual disposable brushes moistened in sterile PBS were inserted into the anal canal and were rotated $360^{\circ}$ as they were withdrawn.

\section{HPV detection and typing}

After collection, cells remaining in the collection devices were washed out into a sterile buffered solution and kept at $-20^{\circ} \mathrm{C}$ for $\mathrm{HPV}$ analysis. Beta-globin amplification was used to assess specimen adequacy for HPV DNA detection. Polymerase chain reaction (PCR)-based assays were carried out in the Laboratorio de Patologia e Hemoterapia do Hospital do Cancer, Fundação Antonio Prudente, São Paulo, Brazil [15].

PCR-positive samples were further typed by restriction fragment length polymorphism according to Bernard et al. [16], allowing the recognition of more than $42 \mathrm{HPV}$ types (HPV6,11, 13, 16, 18, 26, 31, 32, 33, 34, 35, 39, 40, 42, $44,45,51,52,53,54,55,56,57,58,59,61,62,64,66$, $67,68,69,70,71,72,73,81,82,83,84$, LVX100 and CP6108). The following restriction enzymes were used: Bam HI, Dde I, Hae III, Hinf I, Pst I, Rsa I and Sau 3a I (Gibco BRL-Life Technologies, Los Angeles, California, USA). The identification of HPV types was performed by comparing the pattern of amplified bands with those attributed to each virus type. HPV types were classified as high-risk (or probably high-risk) and low-risk types as in Muñoz et al. [17]. Other HPV types that could not be identified in this study were considered unidentified (HPVX).

\section{Statistical analysis}

The Kappa statistic was used to calculate the agreement between HPV positivity at the cervical $v$ s vaginal or anal sites. The concordance rate was considered fair to good if Kappa values were between $0.60-0.80$, and excellent if greater than 0.80. Agreement for any HPV type is defined as presence of at least one common HPV type in the 2 or 3 combined sites. ORs for detection of HPV infection and corresponding $95 \%$ CIs were calculated separately for each anogenital site and for each combination of 2 or 3 sites by means of unconditional regression equations adjusted for age $(<25,25-34, \geq 35)$. The analyses were repeated with adjustment for age and CD4 count $(<200$, $200-499, \geq 500$ ).

\section{Results \\ HPV prevalence by anogenital site}

The prevalence of HPV infection among HIV-positive women did not differ significantly between the three anogenital sites under study. The prevalence was $61.6 \%$ in the cervix, $65.9 \%$ in the vagina, and $63.7 \%$ in the anal area. The same similarity is seen when high-risk HPV types are considered, in the cervix (36.2\%), vagina (42.8\%) and the anal area $(43.1 \%)$. In respect to low-risk HPV types, the prevalence was $34.1 \%$ in the cervix, $35.5 \%$ in the vagina and $33.3 \%$ in the anal area. Multiple HPV infections occurred in $41.2 \%$ of HPV-positive cervical samples, $48.4 \%$ of HPV-positive vaginal samples and $44.6 \%$ of HPV-positive anal samples. The prevalence of HPV types 
according to the risk category in the studied female population was described elsewhere [18].

In the cervix, the most frequent high-risk HPV types were HPV16 and 53 ( $\mathrm{n}=13$ each type) and HPV18 $(\mathrm{n}=12)$ (Table 1). HPV61 and 81 were the most frequent low-risk HPV types ( $\mathrm{n}=11$ and 9 respectively). For $9.4 \%$ of the samples the HPV type could not be characterized.
Similarly, in the vagina, the most frequent high-risk HPV types detected were HPV16, 53 and $18(\mathrm{n}=17,15$ and 12, respectively) (Table 1 ), while the most frequent low-risk HPV types were HPV61 and $81(\mathrm{n}=11$ for each). Thirteen $\%$ of vaginal samples were HPV positive but the HPV type could not be characterized.

Table I: Prevalence of 23 HPV types by collected site among 138 HIV-positive women. Santos, São Paulo, Brazil, 1996-1997

\begin{tabular}{|c|c|c|c|c|c|c|c|c|c|}
\hline & \multicolumn{9}{|c|}{ Site } \\
\hline & \multicolumn{3}{|c|}{ Cervix } & \multicolumn{3}{|c|}{ Vagina } & \multicolumn{3}{|c|}{ Anala } \\
\hline & Single & Multiple & Total (\%) & Single & Multiple & Total (\%) & Single & Multiple & Total (\%) \\
\hline HPV - & & & $53(38.4)$ & & & 47 (34.I) & & & $37(36.3)$ \\
\hline HPV + & 50 & 35 & $85(61.6)$ & 47 & 44 & 91 (65.9) & 36 & 29 & 65 (63.7) \\
\hline HR HPV+ & 23 & 28 & $51(37.0)$ & 25 & 34 & $59(42.8)$ & 16 & 28 & $44(43.1)$ \\
\hline LR HPV+ & 24 & 23 & 47 (34.I) & 19 & 30 & 49 (35.5) & 15 & 20 & $35(34.3)$ \\
\hline \multicolumn{10}{|l|}{ High-risk } \\
\hline 16 & 7 & 6 & $13(9.4)$ & 6 & 11 & $17(12.3)$ & 4 & 5 & $9(8.8)$ \\
\hline 18 & 4 & 8 & $12(8.7)$ & 4 & 8 & $12(8.7)$ & 2 & 10 & $12(11.8)$ \\
\hline 31 & 0 & 5 & $5(3.6)$ & I & 5 & $6(4.3)$ & 2 & 1 & $3(2.9)$ \\
\hline 33 & 3 & 4 & $7(5.1)$ & 1 & 7 & $8(5.8)$ & 2 & 4 & $6(5.9)$ \\
\hline 39 & 0 & I & I (0.7) & I & 0 & I (0.7) & 0 & 1 & I (I.0) \\
\hline 45 & 0 & 2 & $2(1.4)$ & 0 & 2 & $2(1.4)$ & 0 & I & I (I.0) \\
\hline 52 & 0 & 1 & I (0.7) & 0 & 2 & $291.4)$ & 0 & 0 & $0(0.0)$ \\
\hline 53 & 5 & 8 & $13(9.4)$ & 7 & 8 & $15(10.9)$ & 4 & 9 & $13(12.7)$ \\
\hline 56 & I & 0 & I $(0.7)$ & 1 & 1 & $2(1.4)$ & 0 & 1 & $I(1.0)$ \\
\hline 58 & I & 2 & $3(2.2)$ & I & 2 & $3(2.2)$ & 1 & 2 & $3(2.9)$ \\
\hline 59 & I & 0 & I (0.7) & 0 & 0 & $0(0.0)$ & 0 & 0 & $0(0.00$ \\
\hline 66 & 0 & 3 & $3(2.2)$ & 0 & 3 & $3(2.2)$ & 0 & 4 & $4(3.9)$ \\
\hline 68 & I & 1 & $2(1.4)$ & 3 & I & $4(2.9)$ & 1 & 0 & I (I.0) \\
\hline 73 & 0 & 1 & I (0.7) & 0 & I & I (0.7) & 0 & 0 & $0(0.0)$ \\
\hline 82 & 0 & 2 & $2(1.4)$ & 0 & 2 & $2(1.4)$ & 0 & 0 & $0(0.0)$ \\
\hline Subtotal & 23 & 44 & 67 & 25 & 53 & 78 & 16 & 38 & 54 \\
\hline \multicolumn{10}{|l|}{ Low-risk } \\
\hline 6 & 3 & 1 & $4(2.9)$ & 2 & 2 & $4(2.9)$ & 5 & 3 & $8(7.8)$ \\
\hline 11 & 3 & 4 & $7(5.1)$ & 2 & 5 & $7(5.1)$ & 1 & 5 & $6(5.5)$ \\
\hline 32 & 0 & I & I (0.7) & 0 & 1 & I (0.7) & 0 & 0 & $0(0.0)$ \\
\hline 34 & I & 0 & I $(0.7)$ & I & 0 & I $(0.7)$ & 1 & 0 & I (I.0) \\
\hline 40 & 0 & 2 & $2(1.4)$ & 2 & 2 & $4(2.9)$ & 0 & 2 & $2(1.8)$ \\
\hline 54 & I & 1 & $2(1.4)$ & 1 & 2 & $3(2.2)$ & 0 & I & I (1.0) \\
\hline 61 & 4 & 7 & II (8.0) & 3 & 8 & II (8.0) & 2 & 6 & $8(7.3)$ \\
\hline 62 & 0 & 1 & I (0.7) & 0 & I & I (0.7) & 2 & I & $3(2.7)$ \\
\hline 64 & 0 & 1 & I (0.7) & 0 & 0 & $0(0.0)$ & I & 0 & I (I.0) \\
\hline 67 & 2 & 0 & $2(1.4)$ & 0 & I & I (0.7) & 0 & 0 & $0(0.0)$ \\
\hline 69 & 2 & 0 & $2(1.4)$ & 2 & i & $3(2.2)$ & I & 0 & $1(1.0)$ \\
\hline 70 & I & 0 & I $(0.7)$ & 0 & 1 & I (0.7) & 0 & 0 & $0(0.0)$ \\
\hline 71 & 2 & 0 & $2(1.4)$ & I & 1 & $2(1.4)$ & 1 & 0 & I (I.0) \\
\hline 72 & 0 & 2 & $2(1.4)$ & I & 3 & $4(2.9)$ & 0 & 1 & I (1.0) \\
\hline 81 & 2 & 7 & $9(6.5)$ & 2 & 9 & II (8.0) & 0 & 5 & $5(4.6)$ \\
\hline 83 & 2 & 4 & $6(4.3)$ & 1 & 3 & $4(2.9)$ & 1 & 2 & $3(2.7)$ \\
\hline 84 & 1 & 0 & I (0.7) & 1 & 0 & I (0.7) & 0 & 1 & I (1.0) \\
\hline Subtotal & 24 & 31 & 55 & 19 & 40 & 59 & 15 & 27 & 42 \\
\hline Unknown & 3 & 10 & $13(9.4)$ & 3 & 15 & $18(13.0)$ & 5 & 7 & $12(11.8)$ \\
\hline
\end{tabular}

aPresented for 102 HIV-positive women. HPV = human papillomavirus; HIV = human immunodeficiency virus; HR = High-risk; LR = low-risk 
In the anal area, the most frequently detected high-risk HPV types were, in decreasing order, HPV53 $(\mathrm{n}=13), 18$ $(\mathrm{n}=12)$, and $16(\mathrm{n}=9)$. The most frequent low-risk HPV types were HPV 61 and $6(\mathrm{n}=8$ for each). In $11.8 \%$ of anal samples the HPV type could not be characterized. HPV6, but not HPV11, tended to be more frequent in the anal area than in the cervix or vagina $(7.8 \%$ in the anal area $v s$ $2.9 \%$ in each other site).

In respect to cervical and vaginal sites, agreement for any HPV type positivity was $78.3 \%$ (Kappa value $=0.53$ for any type) and varied from $92.8 \%$ (HPV16) to $98.6 \%$ (HPV61 and HPV6). Kappa values above 0.80 were found for HPV18, 33 and 61. When cervical and anal sites were compared, agreement for positivity for any HPV type was found in $68.6 \%$ of women (Kappa value $=0.31)($ Table 2$)$. The Kappa value was particularly low for HPV16 (0.11), but was relatively elevated for HPV18 (0.69), especially concerning the combination among the three sites (0.72).

\section{Risk factors for associations between sites for any HPV positivity}

As shown in Table 3, HPV positivity were inversely associated with age in three combinations of anogenital sites (cervical+anal; vaginal+anal and cervical+vaginal+anal), all of them including anal site. No association emerged in any site between HPV positivity and smoking habits, history of drug addiction, commercial sex work and condom use, and number of years since HIV diagnosis.

Anal intercourse showed an association of borderline statistical significance in the combination vaginal + anal for HPV positivity (OR: 2.4; 95\% CI: 0.97-6.0), but not elsewhere. Nevertheless, condom use did not show associations with HPV positivity at all sites.

\section{Discussion}

Approximately two-thirds of HIV-positive women in our study from Brazil were infected by HPV and the preva- lence of HPV infection was similar in the cervix, vagina and anal area. This also held true for the prevalence of the most frequently detected individual HPV types, notably HPV11, 16, 18, 53 and 61, and for the frequency of multiple-type infections. However, the same HPV type(s) were not always present in the three examined anogenital areas and the agreement in the detection of individual types was better between the cervix and the vagina than between the cervix and the anal area. The type most frequently detected at all three sites was HPV18, mainly on account of its high prevalence in the anal area. Recently, Castle et al. [19] reported that some HPV types (e.g., HPV61, 71 and 72), were more frequently detected in vaginal specimens from hysterectomized women compared to those who had not undergone hysterectomy. Simultaneous HPV infection in different anogenital sites is considered a risk factor for the concomitant occurrence of anal and cervical lesions, especially in HIV-positive women [20-22].

The factors most clearly associated with HPV positivity among HIV-positive women in our study agree with findings from HIV-negative women [23,24]. Although the small number of women available did not allow most presented ORs to reach statistical significance, we did show higher HPV positivity below age 25 than at age 35 or older, as well as among women who reported two recent sexual partners or more. These findings are consistent with the report that recent sexual partners are a stronger determinant of HPV positivity than the lifetime number of sexual partners [25]. No consistent relationship between HPV positivity and smoking habits or condom use have emerged among HIV-negative women [23,24].

Two characteristics stand out as being more strongly associated with HPV positivity in the anal area than in the cervix and vagina, one being history of anal intercourse. This finding suggests that anal infection is associated among women, as it is among bisexual and homosexual men, to direct HPV exposure $[22,26]$. Anal infection, however, can

Table 2: Agreement of HPV type detection by collected site among 138 HIV-positive women. Santos, São Paulo, Brazil: $1996-1997$

\begin{tabular}{|c|c|c|c|c|c|c|c|c|c|c|c|}
\hline \multirow[b]{2}{*}{ HPV type } & \multicolumn{4}{|c|}{ Cervix: Vagina } & \multicolumn{4}{|c|}{ Cervix: Anusa } & \multicolumn{3}{|c|}{ Cervix, Vagina, Anusa } \\
\hline & Cervix only & Vagina only & Both & $\begin{array}{c}\text { Agreement } \\
\text { (Kappa } \\
\text { value) }\end{array}$ & Cervix only & Anal only & Both & $\begin{array}{l}\text { Agreement } \\
\text { (Kappa } \\
\text { value) }\end{array}$ & $\begin{array}{c}\text { Any of the } \\
\text { three }\end{array}$ & All three & $\begin{array}{c}\text { Agreement } \\
\text { (Kappa } \\
\text { value) }\end{array}$ \\
\hline 16 & 3 & 7 & 10 & $92.8(0.63)$ & 9 & 7 & 2 & $84.3(0.1 \mathrm{I})^{\mathrm{b}}$ & 21 & 2 & $79.4(0.32)$ \\
\hline 18 & 2 & 2 & 10 & $97.1(0.82)$ & 2 & 4 & 8 & 94.1 (0.69) & 14 & 7 & $92.2(0.72)$ \\
\hline 53 & 2 & 4 & II & $95.7(0.76)$ & 8 & 9 & 4 & $83.3(0.23)$ & 22 & 4 & $81.4(0.45)$ \\
\hline 6 & $\mathrm{I}$ & 1 & 3 & $98.6(0.74)$ & 0 & 5 & 3 & $95.1(0.52)$ & 8 & 2 & $94.1(0.55)$ \\
\hline I I & 2 & 2 & 5 & $97.1(0.70)$ & 3 & 5 & I & $92.2(0.16)$ & 8 & I & $91.2(0.33)$ \\
\hline 61 & 1 & 1 & 10 & $98.6(0.90)$ & 6 & 5 & 3 & $89.2(0.29)$ & 13 & 3 & $89.2(0.54)$ \\
\hline Any type & 12 & 18 & 73 & $78.3(0.53)$ & 17 & 15 & 50 & $68.6(0.31)$ & 83 & 45 & $59.8(0.40)$ \\
\hline
\end{tabular}

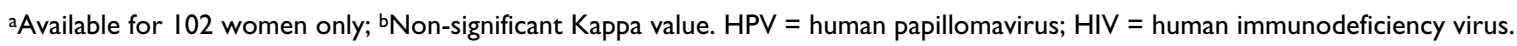


Table 3: ORs ofHPV positivity and corresponding 95\% Cls according to selected characteristics among 138 HIV-positive womena. Santos, São Paulo, Brazil, $1996-1997$

\begin{tabular}{|c|c|c|c|c|c|c|c|c|c|c|c|c|c|c|c|c|}
\hline \multirow{3}{*}{ 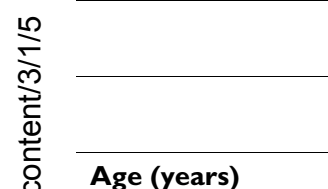 } & \multicolumn{4}{|c|}{ Cervical+Vaginal } & \multicolumn{4}{|c|}{ Cervical+Analb } & \multicolumn{4}{|c|}{ Vaginal+Analb } & \multicolumn{4}{|c|}{ Cervical+Vaginal+Anal ${ }^{b}$} \\
\hline & Tot. No & Pos. (\%) & OR $^{c}$ & $95 \% \mathrm{Cl}$ & Tot. No & Pos. (\%) & OR $^{c}$ & $95 \% \mathrm{Cl}$ & Tot. No & Pos. (\%) & ORc $^{c}$ & $95 \% \mathrm{Cl}$ & Tot. No & Pos. (\%) & ORc & $95 \% \mathrm{Cl}$ \\
\hline & & & & & & & & & & & & & & & & \\
\hline \multirow{4}{*}{ 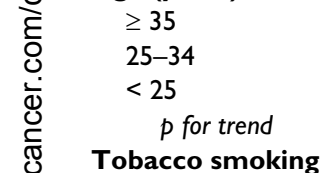 } & 39 & 38.5 & I & & 30 & 10.0 & I & & 30 & 13.3 & I & & 30 & 6.7 & I & \\
\hline & 75 & 49.3 & 1.6 & $0.7-3.4$ & 55 & 27.3 & 3.4 & $0.9-12.8$ & 55 & 34.6 & 3.4 & $1.0-11.3$ & 55 & 27.3 & 5.3 & I.I-24.8 \\
\hline & 24 & 58.3 & 2.2 & $0.8-6.3$ & 17 & 47.1 & 8.0 & $1.7-36.8$ & 17 & 41.2 & 4.6 & $1.1-19.0$ & 17 & 35.3 & 7.6 & $1.3-43.8$ \\
\hline & & & 0.12 & & & & 0.006 & & & & 0.03 & & & & 0.02 & \\
\hline Never smoker & 44 & 45.5 & I & & 32 & 31.3 & I & & 32 & 31.3 & I & & 32 & 21.9 & I & \\
\hline Ex-smoker & 33 & 45.5 & I.I & $0.4-2.8$ & 26 & 30.8 & I.I & $0.3-3.8$ & 26 & 34.6 & 1.2 & $0.4-3.7$ & 26 & 30.8 & 1.7 & $0.5-6.1$ \\
\hline Current smoker & 61 & 50.8 & 1.3 & $0.6-3.0$ & 44 & 18.2 & 0.5 & $0.2-1.7$ & 44 & 25.0 & 0.8 & $0.3-2.2$ & 44 & 18.2 & 0.9 & $0.3-2.9$ \\
\hline$p$ for trend & & & 0.46 & & & & 0.22 & & & & 0.52 & & & & 0.60 & \\
\hline \multicolumn{17}{|l|}{ Drug addict } \\
\hline Never & 79 & 45.6 & I & & 62 & 25.8 & I & & 62 & 25.8 & I & & 62 & 21.0 & I & \\
\hline Ex & 36 & 52.8 & 1.3 & $0.6-2.8$ & 24 & 29.2 & 1.1 & $0.4-3.2$ & 24 & 45.8 & 2.2 & $0.8-6.2$ & 24 & 29.2 & 1.4 & $0.5-4.2$ \\
\hline Current & 23 & 47.8 & 1.0 & $0.4-2.7$ & 16 & 18.8 & 0.7 & $0.2-2.9$ & 16 & 18.8 & 0.6 & $0.2-2.6$ & 16 & 18.8 & 0.8 & $0.2-3.5$ \\
\hline$p$ for trend & & & 0.80 & & & & 0.70 & & & & 0.99 & & & & 0.98 & \\
\hline \multicolumn{17}{|c|}{ Years since HIV diagnosis } \\
\hline$\leq \mathrm{I}$ & 54 & 46.3 & I & & 40 & 27.5 & I & & 40 & 32.5 & I & & 40 & 22.5 & I & \\
\hline $2-4$ & 43 & 39.5 & 0.8 & $0.4-1.9$ & 34 & 60.529 .4 & 1.3 & $0.4-3.8$ & 34 & 32.4 & 1.0 & $0.4-2.8$ & 34 & 26.5 & 1.3 & $0.4-4.2$ \\
\hline$\geq 5$ & 39 & 56.4 & 1.8 & $0.7-4.2$ & 26 & 19.2 & 0.7 & $0.2-2.8$ & 26 & 23.1 & 0.5 & $0.2-1.9$ & 26 & 19.2 & 0.8 & $0.2-3.1$ \\
\hline $\begin{array}{c}p \text { for trend } \\
\text { CD4 count } / \mathrm{mm}^{3}\end{array}$ & & & 0.25 & & & & 0.73 & & & & 0.38 & & & & 0.81 & \\
\hline$\geq 500$ & 34 & 41.2 & I & & 20 & 15.0 & I & & 20 & 15.0 & I & & 20 & 10.0 & I & \\
\hline $200-499$ & 51 & 49.0 & 1.8 & $0.7-4.7$ & 39 & 23.1 & 4.2 & $0.8-22.2$ & 39 & 30.8 & 4.8 & $1.0-22.7$ & 39 & 23.1 & 5.7 & $0.9-34.1$ \\
\hline$<200$ & 53 & 59.9 & 1.8 & $0.7-4.6$ & 43 & 32.6 & 5.9 & 1.2-28.6 & 43 & 34.9 & 5.0 & I.I-22.4 & 43 & 27.9 & 6.2 & I.I-34.9 \\
\hline$p$ for trend & & & 0.24 & & & & 0.03 & & & & 0.06 & & & & 0.06 & \\
\hline \multicolumn{17}{|c|}{ Commercial sex worker } \\
\hline Never & 107 & 46.7 & I & & 82 & 24.4 & I & & 82 & 26.8 & I & & 82 & 20.7 & 1 & \\
\hline Ever & 31 & 51.6 & 1.2 & $0.5-2.6$ & 20 & 30.0 & 1.2 & $0.4-3.8$ & 20 & 40.0 & 1.7 & $0.6-4.8$ & 20 & 30.0 & 1.5 & $0.5-4.6$ \\
\hline \multicolumn{17}{|c|}{$\begin{array}{l}\text { Lifetime number of sexual } \\
\text { partners }\end{array}$} \\
\hline$\leq 2$ & 34 & 41.2 & I & & 26 & 26.9 & I & & 26 & 30.8 & I & & 26 & 26.9 & $\mathrm{I}$ & \\
\hline $3-5$ & 44 & 52.3 & 1.5 & $0.6-3.8$ & 35 & 25.7 & 0.9 & $0.3-2.9$ & 35 & 25.7 & 0.7 & $0.2-2.3$ & 35 & 17.1 & 0.5 & $0.1-1.8$ \\
\hline$\geq 6$ & 60 & 48.3 & 1.2 & $0.5-3.0$ & 41 & 24.4 & 0.7 & $0.2-2.3$ & 41 & 31.7 & 0.8 & $0.3-2.6$ & 41 & 24.4 & 0.7 & $0.2-2.2$ \\
\hline$p$ for trend & & & 0.63 & & & & 0.32 & & & & 0.85 & & & & 0.53 & \\
\hline \multicolumn{17}{|c|}{ Recent sexual partners ${ }^{d}$} \\
\hline 0 & 48 & 43.8 & I & & 42 & 21.4 & I & & 42 & 26.2 & I & & 42 & 21.4 & I & \\
\hline I & 74 & 47.3 & 1.0 & $0.5-2.1$ & 51 & 25.5 & 0.8 & $0.3-2.4$ & 51 & 27.5 & 0.8 & $0.3-2.0$ & 51 & 19.6 & 0.6 & $0.2-1.7$ \\
\hline$\geq 2$ & 13 & 76.9 & 3.5 & $0.8-15.0$ & 9 & 44.4 & 2.2 & $0.5-10.7$ & 9 & 55.6 & 2.6 & $0.5-12.0$ & 9 & 44.4 & 2.0 & $0.4-9.5$ \\
\hline$p$ for trend & & & 0.21 & & & & 0.56 & & & & 0.52 & & & & 0.83 & \\
\hline \multicolumn{17}{|l|}{ Condom use ${ }^{d}$} \\
\hline Yes & 69 & 47.8 & I & & 47 & 25.5 & I & & 47 & 27.7 & I & & 47 & 19.2 & I & \\
\hline No & 20 & 60.0 & 1.7 & $0.6-4.8$ & 13 & 38.5 & 2.0 & $0.5-7.6$ & 13 & 46.2 & 2.4 & $0.7-8.8$ & 13 & 38.5 & 2.9 & $0.7-11.6$ \\
\hline \multicolumn{17}{|l|}{ Anal intercourse } \\
\hline Never & 66 & 48.5 & I & & 51 & 19.6 & I & & 51 & 19.6 & I & & 51 & 19.6 & I & \\
\hline Ever & 72 & 47.2 & 0.9 & $0.5-1.8$ & 51 & 31.4 & 1.7 & $0.6-4.3$ & 51 & 39.2 & 2.4 & $0.97-6.0$ & 51 & 25.5 & 1.2 & $0.5-3.2$ \\
\hline
\end{tabular}

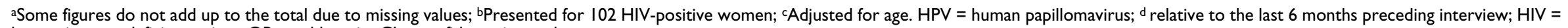
human immunodeficiency virus; $\mathrm{OR}=$ odds ratio; $\mathrm{Cl}=$ confidence intervals. 
also be detected in women who do not report anal intercourse, particularly if a concomitant infection occurs at a genital site $[27,28]$. The other factor that appeared more strongly associated with anal than cervical or vaginal HPV infection was low CD4 counts, thus suggesting that immunosupression may particularly facilitate HPV infection and maybe persistence in the anal area.

One of the limitations of this work is its small sample size. As a consequence, many relatively strong associations did not attain statistical significance. Furthermore, the crosssectional design does not allow for the capture of the dynamic nature of HPV infections. One of the strengths of this study is the wide range of HPV types tested for at different anogenital sites in HIV-positive women.

In conclusion, our study showed that high prevalences of HPV infection can be found in the entire lower genital tract in HIV-positive women. In particular, the anal area may represent a reservoir of HPV infection, notably HPV6 and 18 . It will thus be important to evaluate the efficacy of the current vaccine against HPV $[29,30]$ to prevent not only HPV infection in the cervix but also in the anal area, among immunosuppressed individuals.

\section{Acknowledgements}

M.A.G. Gonçalves was a visiting scientist at IARC, Lyon, France, during the writing of the manuscript. We acknowledge Ms T. Perdrix-Thoma for technical assistance.

\section{References}

I. UNAIDS/WHO: Latin America. UNAIDS/WHO, ed. AIDS Epidemic Update: December 2004. Geneva: UNAIDS/WHO 2004:57-6I.

2. Marins JR, Jamal LF, Chen SY, Barros MB, Hudes ES, Barbosa AA, Chequer $P$, Teixeira PR, Hearst N: Dramatic improvement in survival among adult Brazilian AIDS patients. AIDS 2003, I7:1675-1682.

3. IARC: Monographs on the Evaluation of Carcinogenic Risks to Humans. In Human papillomavirus Volume 64. Lyon: International Agency for Research on Cancer; 1995.

4. Minkoff H, Feldman J, DeHovitz J, Landesman S, Burk R: A longitudinal study of human papillomavirus carriage in human immunodeficiency virus-infected and human immunodeficiency virus-uninfected women. Am J Obstet Gynecol 1998, I 78:982-986.

5. Ahdieh L, Klein RS, Burk R, Cu-Uvin S, Schuman P, Duerr A, Safaeian M, Astemborski J, Daniel R, Shah K: Prevalence, incidence, and type-specific persistence of human papillomavirus in human immunodeficiency virus (HIV)-positive and HIV-negative women. J Infect Dis 200I, 184:682-690.

6. Dal Maso L, Franceschi S, Polesel J, Braga C, Piselli P, Crocetti E, Falcini F, Guzzinati S, Zanetti R, Vercelli M, Rezza G, Cancer and AIDS Registry Linkage study: Risk of cancer in persons with AIDS in Italy, 1985-1998. Br J Cancer 2003, 89:94-100.

7. Branca M, Garbuglia AR, Benedetto A, Cappiello T, Leoncini L, Migliore G, Agarossi A, Syrjanen K, DIANAIDS Collaborative Study Group: Factors predicting the persistence of genital human papillomavirus infections and PAP smear abnormality in HIV-positive and HIV-negative women during prospective follow-up. Int J STD AIDS 2003, 1 4:417-425.

8. Gonçalves MA, Massad E, Burattini MN, Villa LL: Relationship between human papillomavirus (HPV) genotyping and genital neoplasia in HIV-positive patients of Santos City, Sao Paulo, Brazil. Int J STD AIDS 1999, 10:803-807.
9. Palefsky JM, Minkoff H, Kalish LA, Levine A, Sacks HS, Garcia P, Young $M$, Melnick S, Miotti P, Burck R: Cervicovaginal human papillomavirus infection in human immunodeficiency virus- $I$ (HIV)positive and high-risk HIV-negative women. J Natl Cancer Inst 1999, $91: 226-236$.

10. Ellerbrock TV, Chiasson MA, Bush TJ, Sun XW, Sawo D, Brudney K, Wright TC: Incidence of cervical squamous intraepithelial lesions in HIV-infected women. JAMA 2000, 283: I03I-1037.

II. Strickler HD, Palefsky JM, Shah KV, Anastos K, Klein RS, Minkoff H, Duerr A, Massad LS, Celentano DD, Hall C, Fazzari M, Cu-Uvin S, Bacon M, Schuman P, Levine AM, Durante AG, Gange S, Melnick S, Burk RD: Human papillomavirus type 16 and immune status in human immunodeficiency virus-seropositive women. J Natl Cancer Inst 2003, 95:1062-I07I.

12. Canadas MP, Bosch FX, Junquera ML, Ejarque M, Fonte R, Ordonez $E$, de Sanjose S: Concordance of prevalence of human papillomavirus DNA in anogenital and oral infections in a high-risk population. J Clin Microbiol 2004, 42: I330-I332.

13. Drobacheff C, Dupont P, Mougin C, Bourezane Y, Challier B, Fantoli M, Bettinger B, Laurent R: Anal human papillomavirus DNA screening by Hybrid Capture II in human immunodeficiency virus-positive patients with or without anal intercourse. Eur I Dermatol 2003, I3:367-37|

14. Durante AJ, Williams AB, Da Costa M, Darragh TM, Khoshnood K, Palefsky JM: Incidence of anal cytological abnormalities in a cohort of human immunodeficiency virus-infected women. Cancer Epidemiol Biomarkers Prev 2003, I 2:638-642.

15. Manos MM, Wright DT, Lewis AJ: The use of polymerase chain reaction amplification for the detection of human papillomaviruses. In Molecular diagnosis of human cancer: Cancer cells Edited by: Furth M, Greaves M. New York: Cold Spring Harbor Press; 1989:209-2|4.

16. Bernard HU, Chan SY, Manos MM, Ong CK, Villla LL, Delius H, Peyton $C L$, Bauer HM, Wheeler CM: Identification and assessment of known and novel human papillomaviruses by polymerase chain reaction amplification, restriction fragment length polymorphisms, nucleotide sequence, and phylogenetic algorithms. J Infect Dis 1994, 170:1077-1085.

17. Muñoz N, Bosch FX, de Sanjosé $S$, Herrero R, Castellsagué $X$, Shah KV, Snijders PJ, Meijer CJ, International Agency for Research on Cancer Multicenter Cervical Cancer Study Group: Epidemiologic classification of human papillomavirus types associated with cervical cancer. N Engl J Med 2003, 348:5 I 8-527.

18. Gonçalves MA, Burattini MN, Donadi EA, Massad E: Risk factors associated with genital warts in HIV-positive Brazilian women. Tumori 2003, 89:9-15.

19. Castle PE, Schiffman M, Bratti MC, Hildesheim A, Herrero R, Hutchinson ML, Rodriguez AC, Wacholder S, Sherman ME, Kendall H, Viscidi RP, Jeronimo J, Schussler JE, Burk RD: A population-based study of vaginal human papillomavirus infection in hysterectomized women. J Infect Dis 2004, 190:458-467.

20. Hillemanns P, Ellerbrock TV, McPhillips S, Dole P, Alperstein S, Johnson D, Sun XW, Chiasson MA, Wright TC: Prevalence of anal human papillomavirus infection and anal cytologic abnormalities in HIV-seropositive women. AIDS 1996, I0: 1641-1647.

21. Melbye M, Smith E, Wohlfahrt J, Osterlind A, Orholm M, Bergmann OJ, Mathiesen L, Darragh TM, Palefsky JM: Anal and cervical abnormality in women - prediction by human papillomavirus tests. Int J Cancer 1996, 68:559-564.

22. Holly EA, Ralston ML, Darragh TM, Greenblatt RM, Jay N, Palefsky JM: Prevalence and risk factors for anal squamous intraepithelial lesions in women. J Natl Cancer Inst 200I, 93:843-849.

23. Plummer M, Herrero R, Franceschi S, Meijer CJ, Snijders PJ, Bosch FX, de Sanjosé S, Muñoz N, International Agency for Research on Cancer Multicenter Cervical Cancer Study Group: Smoking and cervical cancer: pooled analysis of the IARC multi-centric case - control study. Cancer Causes Control 2003, 14:805-8I4.

24. Thomas JO, Herrero R, Omigbodun AA, Ojemakinde K, Ajavi IO, Fawole A, Oladepo O, Smith JS, Arslan A, Muñoz N, Snijders PJ, Meijer C], Franceschi S: Prevalence of papillomavirus infection in women in Ibadan, Nigeria: a population-based study. Br J Cancer 2004, 90:638-645.

25. Deacon JM, Evans CD, Yule R, Desai M, Binns W, Taylor C, Peto J: Sexual behaviour and smoking as determinants of cervical HPV infection and of CIN3 among those infected: a case- 
control study nested within the Manchester cohort. $\mathrm{Br}$ J Cancer 2000, 83:1565-1572.

26. Daling JR, Madeleine MM, Schwartz SM, Shera KA, Carter JJ, McKnight B, Porter PL, Galloway DA, McDougall JK, Tamimi H: A populationbased study of squamous cell vaginal cancer: HPV and cofactors. Gynecol Oncol 2002, 84:263-270.

27. Williams AB, Darragh TM, Vranizan K, Ochia C, Moss AR, Palefsky JM: Anal and cervical human papillomavirus infection and risk of anal and cervical epithelial abnormalities in human immunodeficiency virus-infected women. Obstet Gynecol 1994, 83:205-2II.

28. Moscicki AB, Durako SJ, Houser J, Ma Y, Murphy DA, Darragh TM, Farhat $S$, Wilson CM: Human papillomavirus infection and abnormal cytology of the anus in HIV-infected and uninfected adolescents. AIDS 2003, 17:3 II-320.

29. Villa LL, Costa RL, Petta CA, Andrade R, Ault K, Giuliano A, Wheeler C, Koutsky L, Malm C, Lehtinen M, Skjeldestad FE, Olsson SE, Steinwall M, Brown DR, Kurman RJ, Ronnett BM, Stoler MH, Ferenczy A, Harper DM, Tamms GM, Yu J, Lupinacci L, Railkar R, Taddeo FJ, Jansen KU, Esser MT, Sings HL, Saah AJ, Barr E: Prophylactic quadrivalent human papillomavirus (types $6,11,16$, and 18 ) $\mathrm{LI}$ virus-like particle vaccine in young women: a randomized double-blind placebo-controlled multicentre phase II efficacy trial. Lancet Oncol 2005, 6:27I-278.

30. Harper DM, Franco EL, Wheeler CM, Moscicki A, Romanowski B, Roteli-Martins C, Jenkins D, Schuind A, Costa Clemens S, Dubin G, HPV Vaccine Study Group: Sustained efficacy up to 4.5 years of a bivalent LI virus-like particle vaccine against human papillomavirus types 16 and 18: follow-up from a randomised control trial. Lancet 2006, 367:1247-55.

\section{Publish with Bio Med Central and every scientist can read your work free of charge}

"BioMed Central will be the most significant development for disseminating the results of biomedical research in our lifetime. "

Sir Paul Nurse, Cancer Research UK

Your research papers will be:

- available free of charge to the entire biomedical community

- peer reviewed and published immediately upon acceptance

- cited in PubMed and archived on PubMed Central

- yours - you keep the copyright

Submit your manuscript here:

http://www.biomedcentral.com/info/publishing_adv.asp 